\begin{tabular}{|c|c|c|}
\hline$=5$ & & $\begin{array}{l}\text { ISSN 2522-9273 (print) } \\
\text { ISSN 2616-5236 (online) }\end{array}$ \\
\hline & & $\begin{array}{l}\text { Economies' Horizons, No. } \\
\text { 4(11), pp. 136-142. }\end{array}$ \\
\hline 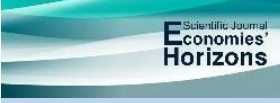 & Homepage: http://eh.udpu.edu.ua & DOI: $\frac{\text { https://doi.org/10.31499/2616- }}{\underline{5236.4(11) .2019 .228709}}$ \\
\hline
\end{tabular}

UDC 338

JEL Classification: M10; M13; R00; R58

\title{
Innovative fundamentals of sports industry development in the new economy
}

\author{
Yaroslav Leonov ${ }^{1}$, Cand. Ec. Sc., Associate Professor
}

\begin{abstract}
The purpose of the research. The purpose of the article is to investigate the problem aspects of the formation of innovative principles of the development of the sports industry in a new economy. Methodology. The theoretical and methodological basis of the study are scientific works of scientists in the field of development of the sports industry. In order to achieve the goal of the following methods of research: generalization and systematization - for the comprehensive characteristics of the analysis of the development of the sports industry in Ukraine; Systemic economic and statistical analysis - for substantiation of the directions of development of the sports industry in Ukraine and generalization and comparison (in the stage of generalization of theoretical provisions and formation of conclusions on this study). Results. The article considers the role of the sports industry in the formation of a new economy. The definition of human capital is considered and its components are determined. Human capital is a system of characteristics that determine a person's ability to work creatively in order to create goods, services, value added, ie the quality of labor of the individual, the total employee of the enterprise, firm, corporation, country, manifested in the process of expanded reproduction. The significance of the innovative approach to creating conditions for the development of the sports industry is determined. The development of a knowledge-based economy is a continuous process of investing in human capital and, consequently, the development of the human personalityOne of the main features of the new economy is its dematerialization. This means a change of emphasis from material goods to intangible (services). Material goods will be consumed, but their share will fall, which is due to changing consumer demand in a new era. The need to study the peculiarities of management of organizations of the sports industry in the conditions of a faster innovative development of physical education and scientific searches in the methodology and the theory of pedagogical management are determined.
\end{abstract}

Keywords: strategic development, sports industry, innovations, knowledge

\footnotetext{
${ }^{1}$ Kharkiv State Academy of Physical Culture, Associate Professor at the Department of Physical Culture Management
} ORCID: https://orcid.org/0000-0001-8837-5744 E-mail: leonov.yaroslav.2017@gmail.com 
economy, education and science system, human capital, human potential.

Number of references: 7; number of tables: 2; number of figures: 0; number of formulas: 0 .

\section{Інноваційні засади розвитку спортивної індустрії в новій економіці}

\section{Я. В. Леонов ${ }^{1}$, к. е. н., доцент}

Анотація. Мета статті - дослідити проблемні аспекти формування інноваційних засад розвитку спортивної індустрії в новій економіці. Методологія. Теоретичною і методологічною основою дослідження $є$ наукові праці вчених у галузі розвитку спортивної індустрії. Для досягнення поставленої в роботі мети були використані такі методи дослідження: узагальнення та систематизації - для всебічної характеристики аналізу розвитку спортивної індустрії в Україні; системного економічного та статистичного аналізу - для обгрунтування напрямів розвитку спортивної індустрії в Україні та узагальнення й порівняння (на етапі узагальнення теоретичних положень і формуванні висновків 3 даного дослідження). Результати. У статті розглянуто роль спортивної індустрії в умовах формування нової економіки. Розглянуто дефініція людський капітал та визначено його складові. Людський капітал - це система характеристик, які визначають здатність людини до творчої праці з метою створення товарів, послуг, доданої вартості, тобто якості робочої сили індивідуума, сукупного працівника підприємства, фірми, корпорації, країни, що знаходять прояв у процесі розширеного відтворення. Визначено значимість інноваційного підходу до створення умов розвитку спортивної індустрії. Розвиток економіки, яка будується на знаннях, $\epsilon$ безперервним процесом інвестування в людський капітал, а отже і розвиток людської особистості. Тому не дивно, що за рівнем конкурентоспроможності економік перші місця в рейтингу економічно розвинутих країн світу займають саме ті країни, які встановлюють високі соціальні стандарти і сприяють всебічному розвитку людини. Одним 3 головних ознак нової економіки є іiі дематеріалізація. Відомо, що організації спортивної індустрії (фізкультурно-спортивні товариства, федерації, спортивні клуби) як правило, невеликі, залежні від можливостей колективу і від професійних взаємин між керівництвом і співробітниками. Практичне значення. Перспективи подальших досліджень. Визначено необхідність дослідження особливостей управління організаціями спортивної індустрії в умовах випереджального інноваційного розвитку фізкультурно-спортивної освіти та наукового пошуку в сторону методології й теорії педагогічного управління.

Ключові слова: стратегічний розвиток, спортивна індустрія, інновації, економіка знань, система освіти і науки, людський капітал, людський потенціал.

Кількість джерел: 7; кількість таблищь: 2; кількість рисунків: 0; кількість формул: 0.

\footnotetext{
${ }^{1}$ Харківська державна академія фізичної культури, доцент кафедри менеджменту фізичної культури ORCID:
} https://orcid.org/0000-0001-8837-5744 E-mail: leonov.yaroslav.2017@gmail.com 
1. Introduction. Transformation processes occurring in the formation of a new Ukrainian economy are characterized by a transition from an economy focused on the production of goods, to an economy based on the production and application of knowledge, from a person's economic to a person creative. In this process, the reform of property relations is carried out, a new system of values, norms and rules, institutional environment are formed, the role of state regulation and influence of branches on the economy of the country are clarified. Not so long ago the subject of the study was labor, labor, labor potential, today is more studied by human capital, human potential, when the socio-psychological problems of man are considered along with difficulties. In this regard, a priority industry affecting the spiritual and physical development of a person is a physical culture and a sports industry.

The sports industry is a specific area of activity due to the results of human activity and the development of sports and recreation services aimed at achieving the desired psychophysiological, human emotional state. Given the division of sports products, their buyers are separate individuals, subjects of economic activity, certain social institutions and a state that are trying to use their athletes at the most prestigious international competitions in order to improve their international image. Physical culture is a component of universal culture. Her basic function is to achieve a person's physical perfection. Contemporary life is impossible without serious changes in the social sphere, one of the main landmarks of which is the state of human health. A healthy lifestyle is a determining factor in ensuring the duration of active life, social, biological and mental well-being of citizens and provides for optimal motor activity, rational nutrition, healthy sleep, compliance with hygienic rules, refusal to smoke, drinking drugs and alcohol abuse, various energy drinks, etc. The social significance of physical culture is also in development, preservation, support of corporal, mental, moral and spiritual health of the population.

\section{Literature review.}

Generalization of achievements of modern management and economic thought from theoretical and methodological issues of an innovative approach to solving strategic socio-economic problems of development of sectoral structures and regions contain the works of domestic and foreign specialists, namely V. Geets and V.P Seminozhenko (2006), O. Dassij (2004), S. Kuznets and M. Friedman, (1945), J. Schumpeter, (1982), etc. However, there are unresolved problems of the formation of value measurement of state and public administration, the creation of theoretical and methodological, philosophical, social and organizational and economic conditions of the development of the sports industry in a new economy.

3. Methods. The theoretical and methodological basis of the study are scientific works of scientists in the field of development of the sports industry. The following methods of research were used in the work, namely: generalization and systematization (in analyzing the development of the sports industry in Ukraine); systematic economic and statistical analysis (when substantiated the directions of development of the sports industry in Ukraine); The method of generalization and comparison (at the stage of generalization of theoretical provisions and formation of conclusions from this study).

4. Research objectives. The purpose of the article is to analyze the 
current state and research of the features of the development of the sports industry on the basis of innovation in the new economy.

5. Results and discussions. The role of knowledge, intelligence, information in human life and society has long raised the interest of scientists, in particular, philosophers, psychologists and culturologists, as a subject of selftheoretical analysis, the economy of knowledge has been established relatively recently - since the intensification of scientific search about nature, the main directions and consequences of the information revolution. The formation of a post-industrial economy has affected not only a gradual movement of society from the economy based on the production of goods, to the economy based on the production and application of knowledge. The main thing is that an extraordinary value acquires a mental work of a person; technologies create global competition;

\section{Table 1. Dynamics of basic indicators of human capital for the period 2008-2014}

\begin{tabular}{|l|c|c|c|c|c|c|c|}
\hline \multicolumn{2}{|c|}{ Indicator } & \multicolumn{7}{|c|}{ Piк } \\
\cline { 2 - 8 } & 2008 & 2009 & 2010 & 2011 & 2012 & 2013 & 2014 \\
\hline $\begin{array}{l}\text { Average expected } \\
\text { life expectancy in } \\
\begin{array}{l}\text { Ukraine at birth, } \\
\text { years (both gender) }\end{array}\end{array}$ & 68,27 & 69,29 & 70,44 & 71,02 & 71,15 & 71,37 & 71,37 \\
\hline $\begin{array}{l}\text { Average duration of } \\
\text { training, years }\end{array}$ & 14,9 & 14,9 & 14,9 & 15,1 & 15,2 & 15,2 & 15,3 \\
\hline $\begin{array}{l}\text { GDP per capita, } \\
\text { dollars. }\end{array}$ & 3891,0 & 2545,5 & 2974,0 & 3570,8 & 3856,8 & 4030,3 & 3014,6 \\
\hline $\begin{array}{l}\text { Budget financing of } \\
\text { education, billion }\end{array}$ & 79,3 & 80,0 & 81,5 & 82,1 & 84,6 & 84,3 & 85,1 \\
\hline $\begin{array}{l}\text { The population of } \\
\text { Ukraine, thousands } \\
\text { of people }\end{array}$ & 46143,7 & 45962,9 & 45778,5 & 45633,6 & 45553,0 & 45426,2 & 42928,9 \\
\hline
\end{tabular}

Source: Ministerstvo molodi ta sportu Ukrainy, 2016 and State Statistics Service of Ukraine, 2015

According to Table 1, it can be concluded that the population of Ukraine during the specified period gradually decreased: in 2014, compared to 2008, the innovation is more important than mass production; Investments are faster invested in new ideas than new equipment. The decisive importance for the knowledge economy acquires human capital, which is an engine of economic growth and development of any country.

Human capital has many measurements and can be acquired in various ways: in educational institutions, in workplaces, houses. The main types of investments in a person are education, professional training, health care, information provision, education of children. Education and professional training increases the amount of human capital; Healthcare increases its duration; Information support contributes to raising prices for human capital services; Education reproduces it in subsequent generations. The assessment of the main indicators of human capital development is given in Table 1.

population declined 3214.8 thousand people. Factors influenced this situation: mortality exceeded fertility, emigration processes. There is a variation of the 
indicator "GDP per capita". The decrease in the value of this indicator in 2009 is due to the influence of the global economic crisis on the Ukrainian economy. The country has a decline in commercial activity of small, medium and large enterprises, which led to an increase in unemployment and has negatively affected the development of human capital. In the period 2010-2013, the value of the indicator "GDP per capita" grew, but in 2014, in connection with the political unstable position and the rapid depreciation of the national currency decreases by $25.2 \%$ and corresponds to the level of 2010 for the period 2008 - In 2014, a population is reduced by $7 \%$, and GDP per capita - by $23 \%$ (or $\$ 876.4$ ). That is, for this period there is only a negative tendency to develop the socio-economic situation of Ukraine, which has adversely affected human capital development. Regarding the average life expectancy of the population, we have a positive tendency to increase the value of the indicator. But the regularity is noted that the life expectancy of women exceeds the life of men.

The development of the economy, which is based on knowledge, is a continuous process of investing in human capital, and therefore the development of a human person. Therefore, it is not surprising that in the level of competitiveness of the economies, the first places in the rating of economically developed countries occupy the countries that establish high social standards and contribute to the comprehensive human development. One of the main features of the new economy is its dematerialization. This means changing accents from material benefits to intangible (services). Material benefits will be consumed, but their share will fall, which is associated with a change in consumer requests in a new era. The knowledge economy brings changes not only from production, but also from consumption. That is, knowledge of these conditions will also be in the role of the factor of production and product.

In 2013, the total expenditures on scientific and scientific and technical works by organizations compared to 2012 increased by $5.7 \%$ and amounted to 11161.1 million UAH. (2012 - UAH 10558.5 million; 2011 - UAH $9591.3 \mathrm{mln}$. UAH). Volume of financial expenses for scientific and scientific and technical works in 2013. At the expense of the state budget increased compared to 2012 by $1.1 \%$ and amounted to UAH 4762.1 million. (2012 - UAH 4709.1 million; 2011 - UAH $3855.7 \mathrm{mln}$.). The share of total expenditures for scientific and scientific and technical work in GDP amounted to $0,77 \%$, including At the expense of the state budget $-0.33 \%$ (The World Factbook, 2015; Ministerstvo molodi ta sportu Ukrainy, 2016 and State Statistics Service of Ukraine, 2015). At the same time, the distribution of funding for the performance of scientific and scientific and technical works on certain branches of sciences stored such a trend (Table 2). For equalization, we note that according to Eurostat, in 2012, the average level of expenditures for research and development of EU-27 countries in GDP amounted to $2.06 \%$. Most of the expenses for research and development was in Finland - 3.55\%, Sweden - 3.41\%, Denmark - $2.99 \%$, Germany - 2.92\%, Austria - 2.84\%, Slovenia $-2.80 \%$, France - $2.26 \%$, Belgium - 2.24\%, Estonia - $2.18 \%$ and Holland - 2.16\%; The smallest - in Romania, Cyprus, Bulgaria, Latvia (from $0.42 \%$ to $0.66 \%$ ) (The World Factbook, 2015). 
Table 2. Distribution of funding for fulfillment of scientific and scientific and technical works on separate branches of sciences, $\%$

\begin{tabular}{|l|c|c|c|}
\hline \multirow{2}{*}{ A branch of science } & \multicolumn{3}{c|}{ Year } \\
\cline { 2 - 4 } & 2005 & 2010 & 2013 \\
\hline Agricultural sciences & 5,50 & 6,10 & 5,70 \\
\hline Construction and architecture & 3,40 & 2,80 & 2,30 \\
\hline Medicine & 3,20 & 4,50 & 3,90 \\
\hline Physical education and sports & 0,03 & 0,06 & 0,06 \\
\hline
\end{tabular}

Source: Ministerstvo molodi ta sportu Ukrainy, 2016 and State Statistics Service of Ukraine, 2015

Financing of expenses for fulfillment of scientific and scientific and technical works on sources of funding on the marked branches of sciences in 2013 has such a structural appearance:

- agricultural sciences: from the state budget $-76.9 \%$; Funds of special purpose assets - $0,3 \%$; Own funds of organizations - 16.2\%; Customers - 6.2\%; Other sources $-0.2 \%$.

- construction and architecture: from the state budget - 25.3\%; funds of special purpose assets - 2.3\%; Own funds of organizations $-2.2 \%$; Customers $-67.5 \%$; Other sources $-2.7 \%$.

- Medicine: from the state budget $67.8 \%$; funds of special purpose assets $0 \%$; Own funds of organizations - 5.2\%; Customers $-26.7 \%$; Other sources $-0.3 \%$.

- Physical education and sports: from the state budget $-94.5 \%$; funds of special purpose assets - $0 \%$; Own funds of organizations - 0.04\%; Customers - 0\%; Other sources - $5.46 \%$ (Ministerstvo molodi ta sportu Ukrainy, 2016 and State Statistics Service of Ukraine, 2015).

It should be noted that in the new conditions, the innovation policy of the development of the sports industry should be guided by: increasing the competitiveness of business entities of all forms of ownership; development of a system of physical culture and sports services with the criterion significance of control of high quality life in each region;
Orientation of all participants in innovation policy to activate research activity in the field.

The driving force of the knowledge economy is innovation, and the source knowledge, education, science. Therefore, it requires a significant increase in the number and quality of intellectual work workers, the widespread introduction of communication technologies, an innovative product that generates constant evolutionary and transformational changes, increasing the ability of all business entities to new conditions of existence. However, knowledge gained by specialists in a training institution has been obsolete after five years (Heiets' and Semynozhenko, 2006 and Datsij, 2004). There is no doubt that the knowledge acquired by a specialist in an educational institution is not fully not enough for its successful work during a professional career. Therefore, it is not accidental XXI century announced UNESCO "Century of Education". It is human being in the XXI century to be inextricably linked with education. To date, the sports industry needs not only professional athletes and trainers, high-quality sports goods, equipment, structures, but also professional managers - sports managers.

Solving these and many other problems requires the reform of domestic higher education in the following areas: 1) Principal review of state educational 
policy; 2) improvement of national educational legislation and system of financing of higher education; 3) development of the information system (information and analytical centers, databases of educational systems, etc.) in order to popularize domestic educational and scientific achievements at the world level; 4) educational intensification of human capital with support on the concept of harmonious development of a student's personality and an orientation to encourage him to independent knowledge and active participation in scientific research; 5) improvement of education system throughout life, education of adults and continuous vocational education; 6) creation in the process of preparing not only deep professional competence, but also the social responsibility of a specialist in solving tasks of scientific and technological progress; 7) the creation of permanent public structures - forums of educators, scholars and establishing their cooperation with similar organizations of other countries; 8) formation of an innovative society through the development of systematized innovation educational activity.

In the situation of new economic relations, most organizations received independence and became even more interested in the effectiveness of collective labor. In such a situation, organizational and managerial activity is complicated by volume and intensification and becomes clear that many in this work depends on the personality of the leader. There were changes in the collective. Organizations are interested in ensuring that each employee is focused on the results of its work, showed the initiative, maximally revealed their creative abilities, was in an atmosphere of a healthy moral climate and took an active part in making decisions.
The advanced training of specialists is one of the conditions for the efficient use of frames based on the concept of continuous education, which is that the specialist does not stop education after receiving a diploma on the end of an educational institution, and continues it throughout a professional life. In order to implement the concept of continuous education in the sphere of the sports industry, there is a system of professional development. At present, for advanced training, the following forms are used: training at the faculties of advanced training of higher educational institutions of sports, physical culture, economic profile; participation in scientific and practical conferences; participation in thematic seminars; independent study of scientific and methodological literature and advanced colleagues experience; the internship. Thus, on the basis of the analysis of European experience and domestic practice, the key innovative principles of development of the sports industry in Ukraine are formed:

1. Formation of conditions for innovative development of the sports industry: organization of training, retraining and advanced training of personnel; Implementation of a softwaretarget approach to financing physical culture and sports organizations.

2. Provision of communication of national educational models with the European structure of qualifications, increase comparability and transparency.

3. Creation of criteria and mechanisms for recognizing and establishing informal types of education in educational and professional activities.

4. Defining basic skills and key competencies. Reducing essential differences with EU countries in the field of basic skills and key competencies. 
5. Implementation of personnel training for the system of training and physical activity throughout life on the following areas of activity: teaching; management; scientific and analytical support; use of the latest technologies; planning of curricula; Support (technical, administrative, organizational).

The specificity of management of the organizations of the sports industry in the conditions of advanced innovation development of physical education and sports education in general requires directions of scientific search as a methodology and the theory of pedagogical administration, as well as methods of development of professional competence of the head of a sports organization.

\section{Conclusions.}

The transition to the knowledge economy has already begun and in some areas it is tangible. In the future, these trends will only increase, and in view of the significant acceleration of socio-economic processes in the XXI century. Construction of knowledge economy in the coming decades is complete reality. Education, Health, Professional training, Finding economically significant information, Mobility of labor, Education and child care relates to the main directions of "human investment". Therefore, the state policy in this direction should become a separate, independent direction of the regulatory function of the government. Organizational and economic activity in the sphere of the sports industry is aimed at meeting the growing needs of the population in a qualitative sports product, a healthy lifestyle, which promotes the development of human capital and will ensure accelerating the innovation development of the country.

\section{References}

Datsij, O. I. (2004), Rozvytok innovatsijnoi diial'nosti v ahropromyslovomu vyrobnytstvi Ukrainy [Development of innovative activity in agro-industrial production of Ukraine], NNTs IAE, Kyiv, Ukraine.

Heiets', V. M. and Semynozhenko, V. P. (2006), Innovatsijni perspektyvy Ukrainy,[Innovative prospects of Ukraine] Konstanta, Kharkiv, Ukraine.

Kuznets, S. and Friedman, M. (1945), Income from Independent Professional Practice, N.Y, USA.

Ministerstvo molodi ta sportu Ukrainy (2016), "Zvit z fizychnoi kul'tury i sportu", [Online], http://dsmsu.gov.ua/index/ua/category/55 (access date 11.02.2015)

Shumpeter, J. (1982) Teoryia ekonomycheskoho razvytyia: Yssledovanyia predprynymatel'skoj prybyly, kapytala, kredyta y tsykla kon'iuktury, [Economic Development Theory: Research on Entrepreneurial Profit, Capital, Credit, and the Business Cycle], Prohress, Moscow, Russia.

State Statistics Service of Ukraine (2015), "Statistical Yearbook 2015", access mode: http://www.ukrstat.gov.ua (access date 11.02.2015)

The World Factbook: [Online], URL: https://www.cia.gov/library/publications/theworld-factbook/rankorder/2054rank.html (access date 11.02.2015) 